\title{
Molecular Targeted Agents for Hepatocellular Carcinoma: Current Status and Future Perspectives
}

Prof. M. Kudo

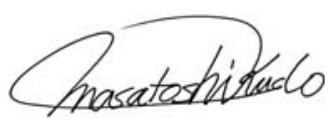

Editor Liver Cancer

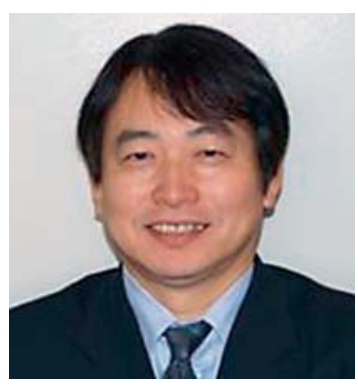

\section{Introduction}

Locoregional therapy is the primary treatment for hepatocellular carcinoma (HCC). Sorafenib was approved as a first-line systemic therapy for advanced HCC with associated extrahepatic spread and/or vascular invasion in 2007. However, there are several limitations associated with sorafenib therapy. To overcome these problems, various clinical trials have been conducted to develop additional molecular targeted agents for HCC. However, all of the clinical trials conducted thus far, except for a recent trial using regorafenib, have been unsuccessful, emphasizing the difficulties associated with drug development for HCC. In this editorial, we review the current status and future prospects of molecular targeted agents that are being developed for HCC.

\section{Sorafenib}

The multikinase inhibitor sorafenib was the first oral molecular targeted agent to show a survival benefit in patients with HCC $[1,2]$. In Japan, sorafenib was approved for national health insurance coverage in May 2009, and it has since been administered to more than 26,000 patients. 
Kudo: Molecular Targeted Agents for Hepatocellular Carcinoma: Current Status and Future Perspectives

Table 1. Phase III clinical trials for HCC

\begin{tabular}{|c|c|c|c|c|c|}
\hline \multicolumn{2}{|c|}{ Target population } & \multirow{2}{*}{$\begin{array}{l}\text { Design } \\
\text { 1. Peretinoin vs. placebo } \\
\text { 2. Sorafenib vs. placebo } \\
\text { a } \\
\text { 3. Peretinoin vs. placebo }\end{array}$} & \multirow{2}{*}{$\begin{array}{l}\text { Trial name } \\
\text { NIK-333 } \\
\text { STORM } \\
\text { NIK-333/K-333 }\end{array}$} & \multirow{2}{*}{$\begin{array}{l}\text { Presentation } \\
\text { ASCO } 2010 \\
\text { ASCO } 2014 \\
\text { Ongoing }\end{array}$} & \multirow{2}{*}{$\begin{array}{l}\text { Publication } \\
\text { JG } 2014 \\
\text { Lancet-0 } 2015\end{array}$} \\
\hline Early & $\begin{array}{l}\text { Adjuvant } \\
\text { (prevention of } \\
\text { recurrence) }\end{array}$ & & & & \\
\hline Intermediate & $\begin{array}{l}\text { Improvement of } \\
\text { TACE }\end{array}$ & $\begin{array}{l}\text { 1. TACE +/- sorafenib } \\
\text { 2. TACE +/- brivanib } \\
\text { 3. TACE +/- orantinib }\end{array}$ & $\begin{array}{l}\text { Post-TACE } \\
\text { BRISK-TA } \\
\text { ORIENTAL }\end{array}$ & $\begin{array}{l}\text { ASCO-GI } 2010 \\
\text { ILCA } 2013 \\
\text { EASL } 2015\end{array}$ & $\begin{array}{l}\text { EJC } 2011 \\
\text { Hepatol } 2014\end{array}$ \\
\hline Advanced & Second line & $\begin{array}{l}\text { 1. Sorafenib vs. sunitinib } \\
\text { 2. Sorafenib vs. brivanib } \\
\text { 3. Sorafenib vs. linifanib } \\
\text { a } \\
\text { 4. Sorafenib +/- HAIC } \\
\text { 5. Sorafenib vs. lenvatinib } \\
\text { 6. Sorafenib vs. nivolumab } \\
\text { 1. Brivanib vs. placebo } \\
\text { 2. Everolimus vs. placebo } \\
\text { 3. Ramucirumab vs. placebo } \\
\text { 4. S-1 vs. placebo } \\
\text { 5. Regorafenib vs. placebo } \\
\text { 6. Tivantinib vs. placebo } \\
\text { 7. Ramucirumab vs. placebo } \\
\text { 8. Pembrolizumab vs. placebo }\end{array}$ & $\begin{array}{l}\text { SUN1170 } \\
\text { BRISK-FL } \\
\text { LiGHT } \\
\text { SILIUS } \\
\text { REFLECT } \\
\text { CheckMate } 459 \\
\text { BRISK-PS } \\
\text { EVOLVE-1 } \\
\text { REACH } \\
\text { S-CUBE } \\
\text { RESORCE } \\
\text { JET-HCC } \\
\text { REACH-2 } \\
\text { KEYNOTE-240 }\end{array}$ & $\begin{array}{l}\text { ASCO } 2011 \\
\text { AASLD } 2012 \\
\text { ASCO-GI } 2013 \\
\text { EASL } 2016 \\
\text { Ongoing } \\
\text { Ongoing } \\
\text { EASL 2012 } \\
\text { ASCO-GI 2014 } \\
\text { ESMO 2014 } \\
\text { ASCO 2015 } \\
\text { WCGI 2016 } \\
\text { Ongoing } \\
\text { Ongoing } \\
\text { Ongoing }\end{array}$ & $\begin{array}{l}\text { JCO } 2013 \\
\text { JAMA } 2014 \\
\text { Lancet-0 } 2015\end{array}$ \\
\hline
\end{tabular}

HAIC, hepatic arterial infusion chemotherapy. ${ }^{a}$ RCT halted or with negative results. ${ }^{b}$ RCT with positive results.

\section{Current Status of the Development of Molecular Targeted Agents}

Clinical trials are being conducted to develop molecular targeted agents for various stages of liver cancer, including the following: early-stage HCC, in which surgical resection or radiofrequency ablation is indicated; intermediate-stage HCC, in which transcatheter arterial chemoembolization (TACE) is indicated; and advanced-stage HCC, in which sorafenib is indicated.

\section{Early-Stage HCC}

The Sorafenib as Adjuvant Treatment in the Prevention of Recurrence of Hepatocellular Carcinoma (STORM) study, in which sorafenib was used to suppress HCC recurrence after curative therapy, revealed no difference in recurrence-free survival between the sorafenib and placebo groups, demonstrating that sorafenib was not efficacious at suppressing recurrence [3].

Peretinoin, an orally administered acyclic retinoid agent, is structurally similar to vitamin A and functions as a transcription activator and an inducer of differentiation. It is thought to remove precancerous HCC cells by inducing apoptosis and to inhibit carcinogenesis by promoting differentiation. A phase II/III study was launched to investigate the ability of peretinoin to suppress HCC recurrence, but the efficacy of peretinoin could not be evaluated due to problems with dosing [4]. A follow-up phase III trial has been initiated now that the dosing problems have been addressed (Table 1). 


\section{Liver Cancer}

\section{Intermediate-Stage HCC}

Residual tumor and tumor recurrence are inevitable after TACE, because it is not a curative therapy. Since TACE can itself induce angiogenesis, the use of antiangiogenic agents after TACE greatly suppresses tumor recurrence and regrowth, and may even extend the duration of tumor suppression by TACE. This allows TACE to be performed less frequently, enabling preservation of liver function. Globally, many clinical trials have investigated the efficacy of sorafenib as a post-TACE adjuvant therapy. A study in Japan and Korea investigated time to progression (TTP) in patients treated with sorafenib after TACE but found that sorafenib did not prolong TTP in these patients [5].

In the SPACE study, a phase II study of sorafenib or placebo in combination with TACE with doxorubicin drug-eluting beads [6], the primary endpoint of TTP was achieved; however, the study outcome was considered negative because of the clinically insignificant difference between the sorafenib and placebo arms. Other large-scale studies, such as the Eastern Cooperative Oncology Group (ECOG) 1208 study and the TACE2 study, had to be discontinued due to insufficient enrollment. The outcome of the TACE2 study was reported in detail at the 2016 American Society of Clinical Oncology (ASCO) Annual Meeting [7]. The Transcatheter Arterial Chemoembolization Therapy in Combination with Sorafenib (TACTICS) study conducted in Japan is the only large-scale clinical trial that is currently underway. As shown in Table 1, negative outcomes have also been reported in studies with other agents, including the Brivanib versus Placebo as Adjuvant Therapy to Transarterial Chemoembolization in Patients with Unresectable Hepatocellular Carcinoma (BRISK-TA) study [8], a phase III study on brivanib (an inhibitor of vascular endothelial growth factor receptor [VEGFR] and fibroblast growth factor receptor [FGFR]), and the Orantinib in Combination with Transcatheter Arterial Chemoembolization in Patients with Unresectable Hepatocellular Carcinoma (ORIENTAL) study, a phase III study on orantinib (an inhibitor of VEGFR, platelet-derived growth factor receptor [PDGFR], and FGFR [9]).

\section{Advanced-Stage HCC}

Many trials have been conducted to develop molecular targeted agents that can replace sorafenib as a more potent and safe first-line therapy. However, the superiority or noninferiority of sunitinib, brivanib, and linifanib to sorafenib could not be proven [10-12]. A phase III study comparing lenvatinib and sorafenib has recently been concluded, and the results are eagerly awaited. The target molecules of lenvatinib are VEGFR1-3, FGFR1-4, RET, and c-Kit.

Clinical trials of brivanib, everolimus (an inhibitor of mTOR [mechanistic target of rapamycin]), and ramucirumab (a human monoclonal antibody against VEGFR2) were conducted with the aim of developing second-line agents for patients unresponsive to or intolerant of sorafenib, but they failed to show superiority to the placebo (Table 1) [13-15]. However, because ramucirumab was highly effective in a group of patients with elevated serum $\alpha$-fetoprotein (AFP), a phase III study of ramucirumab is currently underway on patients with serum AFP levels $\geq 400 \mathrm{ng} / \mathrm{ml}$. Recently, on June 30,2016, positive data from the RESORCE study of regorafenib, an inhibitor of a broad range of kinases including VEGFR, PDGFR, FGFR, TIE2, Kit, RET, and RAF, were presented at the World Congress on Gastrointestinal Cancer (WCGC). As a groundbreaking result, overall survival (OS), the primary endpoint of the study, was significantly improved in patients that received regorafenib as a second-line therapy (median survival time: 10.6 months, vs. 7.8 months in the placebo group; hazard ratio: 0.62 ; $95 \%$ confidence interval: $0.50-0.78 ; p<0.001$ ) (Table 2 ). Importantly, the study design might have contributed to the positive outcome. First, the study included a group of patients who progressed while on sorafenib, but these patients were required to have received $\geq 400 \mathrm{mg}$ of sorafenib for at least 20 of 28 days prior to enrollment in the RESORCE trial; patients who discontinued sorafenib due to poor tolerability were excluded. Second, vascular invasion and extrahepatic spread were treated as independent stratification factors because 
Kudo: Molecular Targeted Agents for Hepatocellular Carcinoma: Current Status and Future Perspectives

Table 2. Results of the RESORCE trial

\begin{tabular}{lcll}
\hline & Regorafenib & Placebo & HR $(95 \% \mathrm{CI}) ; p$ value \\
\hline Subjects, $n$ & 379 & 194 & \\
BCLC stage C, \% & 88 & 87 & \\
Treatment duration, months & $3.6(0.03-29.4)$ & $1.9(0.2-27.4)$ & \\
OS, months & 10.6 & 7.8 & $0.62(0.50-0.78) ; p<0.001$ \\
PFS, months & 3.1 & 1.5 & $0.46(0.37-0.56) ; p<0.001$ \\
TTP, months & 3.2 & 1.5 & $0.44(0.36-0.55)$ \\
DCR, \% & 65.2 & 36.1 & $p<0.001$ \\
ORR, \% & 10.6 & 4.1 & $p<0.005$ \\
Adverse events grade $\geq 3, \%$ & 79.7 & 58.5 & \\
\hline
\end{tabular}

BCLC, Barcelona Clinic Liver Cancer; OS, overall survival; PFS, progression-free survival; TTP, time to progression; DCR, disease control rate; ORR, overall response rate; HR, hazard ratio; CI, confidence interval.

Table 3. Imbalance between the brivanib and placebo arms

\begin{tabular}{|c|c|c|c|c|}
\hline \multirow[t]{2}{*}{ Demographic or characteristic } & \multicolumn{2}{|c|}{$\begin{array}{l}\text { Brivanib } \\
(n=263)\end{array}$} & \multicolumn{2}{|c|}{$\begin{array}{l}\text { Placebo } \\
(n=132)\end{array}$} \\
\hline & $n$ & $\%$ & $n$ & $\%$ \\
\hline \multicolumn{5}{|l|}{ Reason for sorafenib discontinuation } \\
\hline Progression & 227 & 86 & 116 & 88 \\
\hline Intolerance & 35 & 13 & 16 & 12 \\
\hline Distant metastasis & 171 & 65 & 84 & 64 \\
\hline Vascular invasion & 81 & 31 & 24 & 18 \\
\hline Portal vein invasion and/or thrombosis & 65 & 25 & 16 & 12 \\
\hline
\end{tabular}

of the lessons learned from the failed brivanib trial (Table 3). As for other agents, a clinical trial of the c-MET inhibitor tivantinib is currently underway (Table 1).

\section{Problems Associated with Clinical Trials of Molecular Targeted Agents for HCC}

As stated above, numerous drug development trials ended with negative outcomes, and a number of potential reasons for these results have been proposed.

\section{Problems Associated with the Heterogeneity of HCC}

Compared with other types of cancer, HCC is very heterogeneous. In particular, HCC is a multicentric tumor, and its characteristics can vary from nodule to nodule, even within an individual patient. Consequently, the efficacy of molecular targeted agents is highly variable. Clinical trials use the Child-Pugh liver function score and the TNM tumor stage as inclusion criteria. Thus, a seemingly clinically homogeneous group of patients included in a study may actually be biologically heterogeneous. Therefore, to restrict the patient population to a biologically homogeneous group, drug development trials have started to rely on biomarkers [16]. A representative example is a trial of tivantinib, which inhibits the hepatocyte growth factor receptor c-MET [17]. This phase II study has shown the efficacy of tivantinib in patients with HCC expressing high levels of c-MET, even though in this group of patients, the prognosis is generally poor. Currently, a placebo-controlled phase III study is being conducted only on 


\section{Liver

patients with tumors expressing high levels of c-MET. However, selecting patients based on biomarkers does not address the problem of tumor characteristics varying from nodule to nodule within the same patient. In other words, the possibility of sampling variability cannot be eliminated. Indeed, the outcome of a study using a mutation of RAS as a biomarker to investigate the efficacy of the MEK inhibitor refametinib was also unfavorable. These problems may be resolved once more effective serum biomarkers are identified. A phase II clinical trial of the TGF (transforming growth factor)- $\beta$ receptor inhibitor galunisertib is currently underway, and improved OS and reduced TGF- $\beta_{1}$ levels in patients with normal AFP values were reported at the 2016 ASCO Annual Meeting [18].

\section{Problems Associated with Stratification Factors}

In general, stratification factors are stipulated to prevent bias during randomization. The proper handling of vascular invasion and extrahepatic spread is considered important in patients with HCC. The design of many ongoing clinical trials involves an allocation factor specifying "either vascular invasion or extrahepatic spread" or "neither vascular invasion nor extrahepatic spread." However, because vascular invasion is an extremely poor prognostic factor for HCC, assigning vascular invasion to the same category as extrahepatic spread may have influenced the outcome of clinical trials. In other words, if the active drug group contains more patients with vascular invasion while the placebo group includes more patients with extrahepatic spread, such a sampling bias will put the active drug groups at a disadvantage. In fact, this actually happened in a clinical trial of brivanib as second-line therapy (Table 3) [13]. In the RESORCE trial, which reported a positive outcome, patients were stratified separately by vascular invasion and by extrahepatic spread [19].

\section{Influence of Post-Trial Treatment}

Post-progression survival (PPS) is defined as the interval between a diagnosis of progressive disease and the patient's death; OS is expressed by the equation OS = PFS + PPS, where PFS is progression-free survival. Even when a statistical difference in PFS is observed, this might not be reflected in OS if PPS is sufficiently long. Indeed, OS correlated with PPS more strongly than with PFS in a clinical trial of sorafenib [20]. Locoregional therapy is the mainstay of treatment for HCC, but molecular targeted agents are indicated for cases where locoregional therapy is no longer practical. However, even after following the recommended therapeutic guidelines, locoregional therapy is often applied as a post-trial treatment, if the patient's general condition is stable. This rarely happens with other types of cancer and is an issue unique to HCC due to the availability of effective locoregional therapies such as intraarterial infusion chemotherapy or TACE. It is therefore possible that if PPS is prolonged by effective post-trial treatments, there may be no significant difference in $O S$, the primary endpoint of the trial [21]. In addition, clinical trials of agents other than regorafenib use intolerability to sorafenib as an inclusion criterion; however, this is thought to augment the influence of post-trial treatments. Patients who progressed after administration of sorafenib are defined as unresponsive to sorafenib; they have a relatively advanced tumor burden and are in poor condition overall. By contrast, patients defined as intolerant to sorafenib, who discontinued the treatment due to adverse events, remain in a relatively stable condition. Clinically stable patients are more likely to be subjected to various post-trial treatments, particularly to locoregional therapy, regardless of whether they have received a second-line agent or a placebo during the trial. The outcome of a subanalysis of a phase II study of axitinib supports this contention. This analysis revealed that OS in the axitinib arm was much better than in the placebo arm when patients who discontinued therapy due to adverse events were excluded [22]. Taking this into consideration, clinical trials of second-line agents should enroll only those patients unresponsive to sorafenib, as was done in the RESORCE study [19]. 


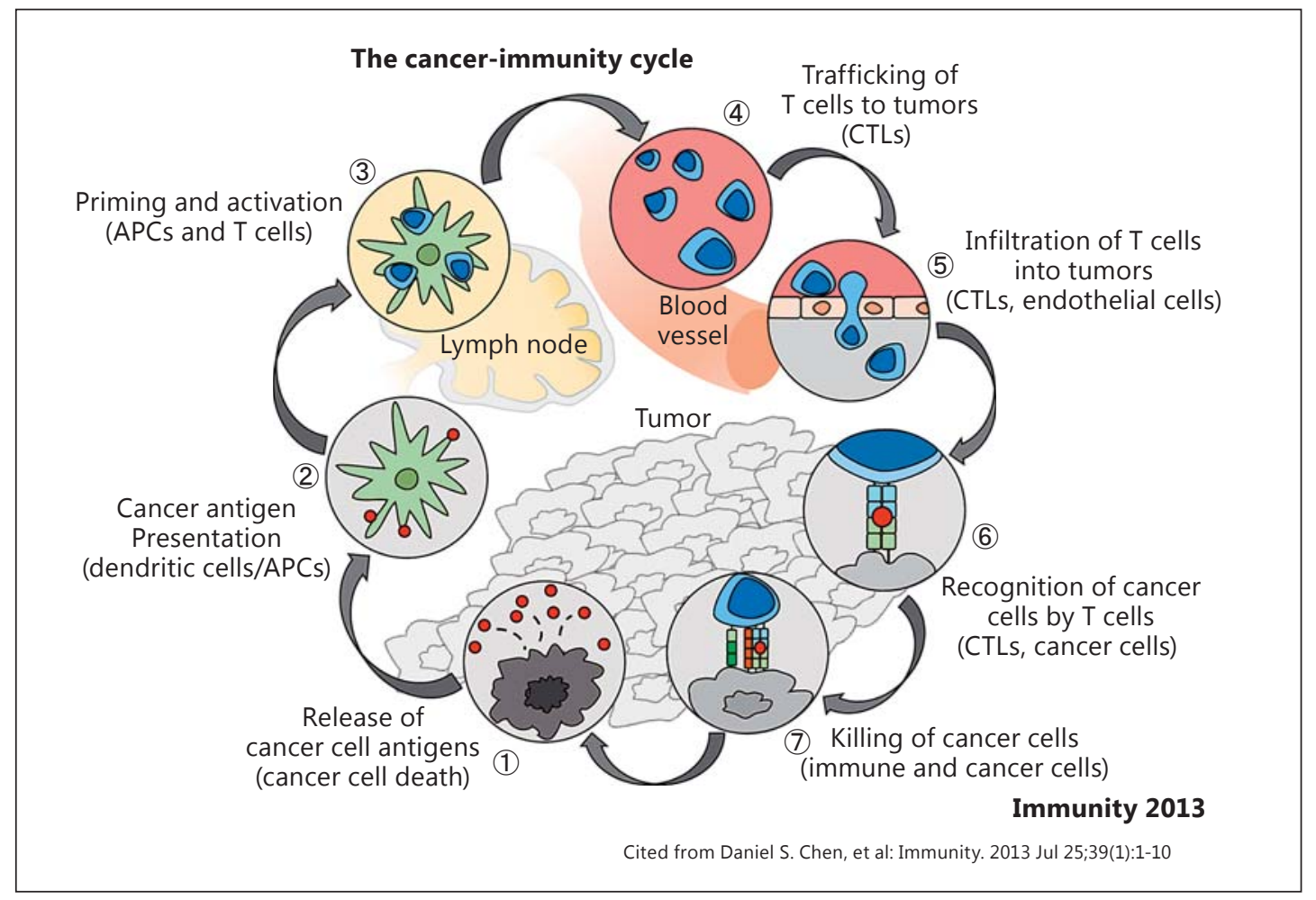

Fig. 1. The cancer-immunity cycle. Naïve T cells are activated by signals from antigen-presenting cells (APCs), which recognize the cancer cell antigens in the lymph node. At the tumor, activated T cells attack the cancer cells. CTLs, cytotoxic T lymphocytes.

As stated earlier, the clinical trial of regorafenib excluded patients intolerant to sorafenib. This decision was made primarily because regorafenib and sorafenib have similar toxicological profiles due to their structural similarity [19]. However, because patients intolerant to sorafenib were excluded, post-trial treatments were limited, resulting in a favorable outcome. This superior trial design resulted in a shorter PPS and therefore a greater difference in OS, clarifying the benefits of regorafenib therapy.

\section{Hepatic Functional Reserve}

Since many patients with HCC have an underlying chronic liver disease, such as cirrhosis, it is important to consider the effect of therapy on liver function. Most clinical trials enroll patients with Child-Pugh class A liver function (Child-Pugh score of 5-6 points). However, prognoses differ substantially between patients with a score of 5 and those with 6 points. Therefore, in the case of HCC, it may be necessary to include Child-Pugh scores of 5 and 6 as separate stratification factors.

\section{Immune Checkpoint Inhibitors}

An antibody against programmed cell death protein 1 (PD-1) has been gaining attention as an immune checkpoint inhibitor in recent years (Fig. 1-3). At the 2015 ASCO Annual Meeting, a phase I study of anti-PD-1 (nivolumab) in patients with HCC reported a favorable outcome, with 2 complete and 7 partial responses and an overall response rate of $19 \%$ [23]. 


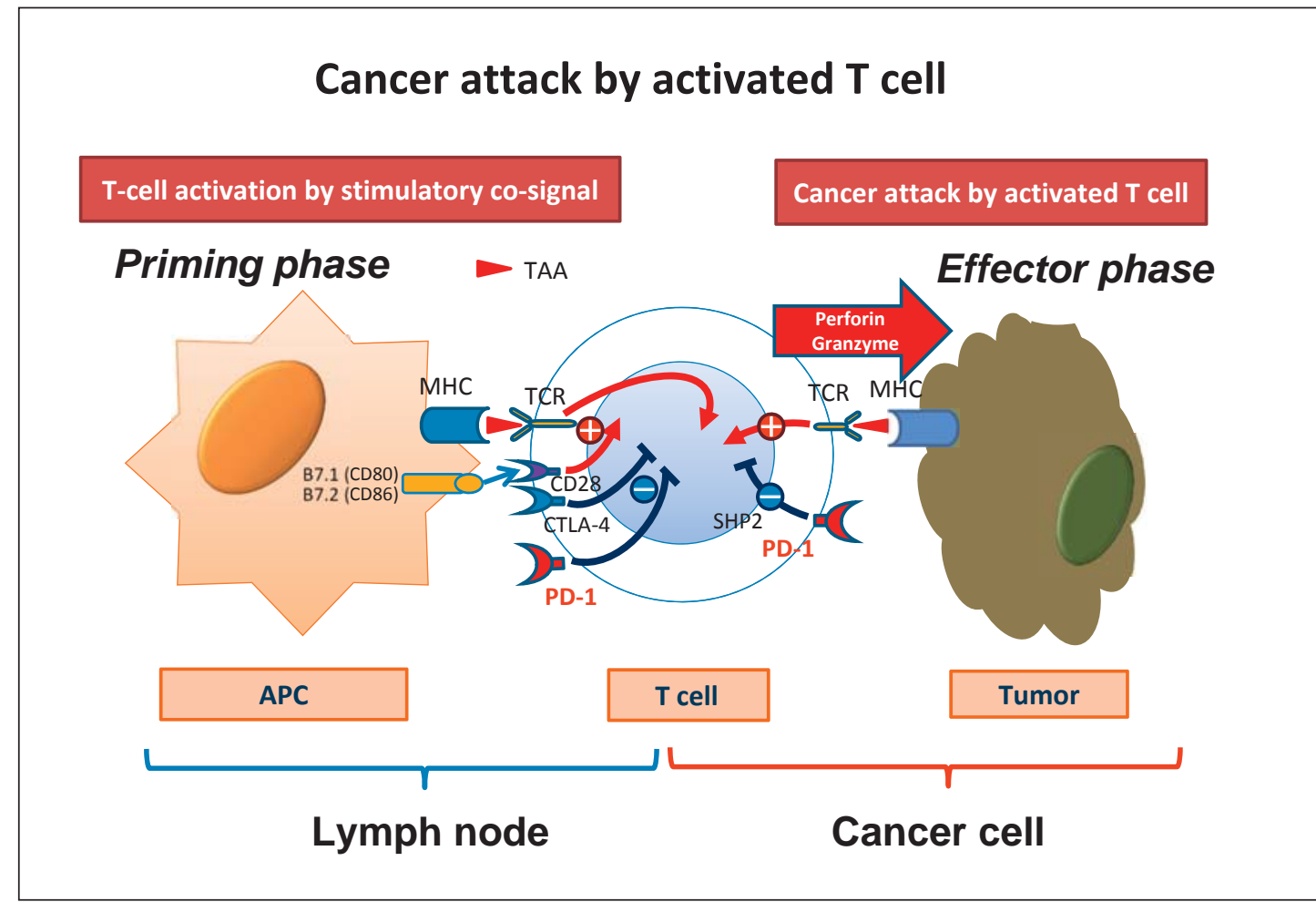

Fig. 2. After the recognition of tumor-associated antigen (TAA) by the T-cell receptor (TCR), a co-stimulatory signal by binding B7 and CD28, naïve T cells are activated. Consequently, the activated T cells attack the cancer cells by recognizing the TAA. Cancer cells are killed by activated $\mathrm{T}$ cells by producing perforin and granzyme. APC, antigen-presenting cell.

In Japan, a phase I/II study of nivolumab with dose expansion cohorts began in the summer of 2015. The outcomes of the dose escalation and dose expansion trials were reported at the 2016 ASCO Annual Meeting [24, 25] (Table 4). Furthermore, other reports included the design of a phase III clinical trial [26] and a study of combination therapy with anti-PD-1 and cytotoxic T-lymphocyte-associated protein 4 (CTLA-4) (Tables 5, 6) [27]. However, due to extremely expensive drug prices, it is very likely that the medical costs of these agents will strain nations' finances when approved for clinical use. Therefore, an urgent challenge today is to discover biomarkers that predict treatment response and thus offer a clear indication for their use.

\section{Master Protocols}

Drug development trials have high research and development costs and also require a huge effort to recruit participants. In the USA, the Lung Cancer Master Protocol (Lung-MAP) for patients with squamous cell lung cancer was launched in 2014 (Fig. 4) [28]. Patients were screened for alterations in cancer-related genes and were assigned to a trial arm best suited to each subject's genomic profile. This streamlined patient registration made the process more efficient, helping to reduce drug development costs. From the perspective of medical cost reduction, it may become possible to assign an appropriate agent to each patient. Clearly, this will be also extremely beneficial for patients with HCC and we await its early incorpo- 


\section{Immune escape using immune checkpoint molecule}

\section{T-cell inactivation by inhibitory co-signal \\ Immune tolerance/escape}

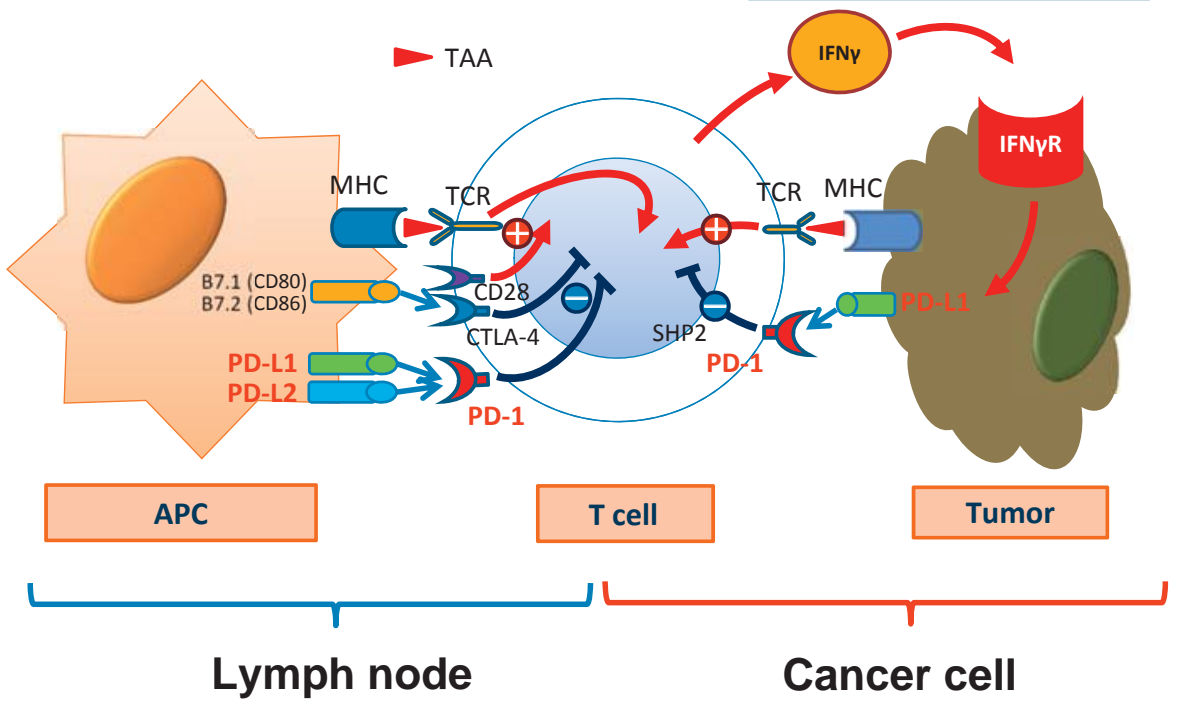

Fig. 3. The immune checkpoint molecules PD-1, PD-L1, and CTLA-4 play an impact role in the cancer's escape from activated T cells (cancer immunotolerance/escape). APC, antigen-presenting cell; TAA, tumor-associated antigen; TCR, T-cell receptor.

Table 4. Objective response to nivolumab

\begin{tabular}{|c|c|c|c|c|c|}
\hline & $\begin{array}{l}\text { Uninfected: } \\
\text { sorafenib naïve/ } \\
\text { intolerant } \\
(n=54)\end{array}$ & $\begin{array}{l}\text { Uninfected: } \\
\text { sorafenib } \\
\text { progressors } \\
(n=58)\end{array}$ & $\begin{array}{l}\text { HCV } \\
(n=51)\end{array}$ & $\begin{array}{l}\text { HBV } \\
(n=51)\end{array}$ & $\begin{array}{l}\text { Total } \\
(n=214)\end{array}$ \\
\hline Objective response & $11(20)$ & $11(19)$ & $7(14)$ & $6(12)$ & $35(16)$ \\
\hline Partial response & $0(0)$ & $2(3)$ & $0(0)$ & $0(0)$ & $2(1)$ \\
\hline Stable disease & $32(59)$ & $27(47)$ & $29(57)$ & $23(45)$ & $111(52)$ \\
\hline Progressive disease & $11(20)$ & $18(31)$ & $12(24)$ & $22(43)$ & 63 (29) \\
\hline Not evaluable & $0(0)$ & $2(3)$ & $3(6)$ & $0(0)$ & $5(2)$ \\
\hline
\end{tabular}

Data are presented as $n(\%)$. Cited from El-Khoueiry et al. [25]. HCV, hepatitis C virus; HBV, hepatitis B virus.

ration. Such results could contribute substantially to the health care economy. Of course, this cannot be achieved by a single pharmaceutical manufacturer but requires the cooperation of multiple manufacturers. Public organizations should also be involved, so that this effort can be made within a public-private integrated project. In Japan, a similar project, SCRUM-Japan, was launched for patients with lung and gastrointestinal cancer including hepatobiliary and pancreatic cancer. Headed by the National Cancer Center, it is currently being tested at various institutions. 
Kudo: Molecular Targeted Agents for Hepatocellular Carcinoma: Current Status and Future Perspectives

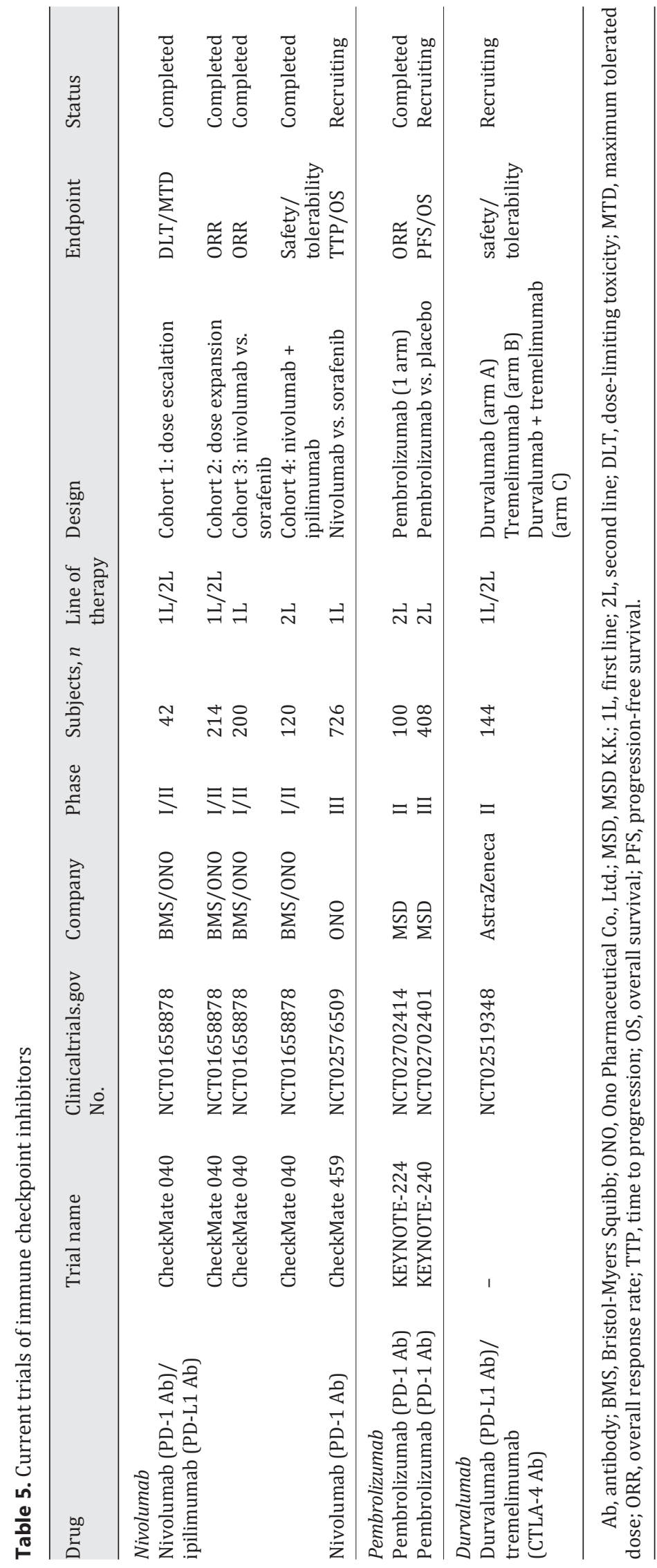


Kudo: Molecular Targeted Agents for Hepatocellular Carcinoma: Current Status and Future Perspectives

Table 6. Clinical trials of CTLA-4 antibody in hepatocellular carcinoma

\begin{tabular}{|c|c|c|c|c|c|c|}
\hline NCT No. & Agent & Design & Status & Subjects, $n$ & Stage & Results \\
\hline 01008358 & Tremelimumab & II & Complete & 20 & III/IV & $\begin{array}{l}\mathrm{PR}=17.6 \%, \mathrm{DCR}=76 \% \\
\mathrm{TTP}=6.5 \text { months } \\
\text { HCV virologic response } \\
\text { Grade } 3 \text { AST } / \text { ALT }=45 \%\end{array}$ \\
\hline 01853618 & $\begin{array}{l}\text { Tremelimumab + } \\
\text { TACE/RFA/cryoablation }\end{array}$ & I & Ongoing & $\begin{array}{l}29 \\
\text { (14 TACE; } \\
10 \text { RFA; } \\
5 \text { cryoablation) }\end{array}$ & III/IV & $\begin{array}{l}\text { Safe, feasible } \\
\text { Immune cell infiltration }(+) \\
\text { TTP = 5.7 months } \\
\text { Reduction in HCV viral load }\end{array}$ \\
\hline
\end{tabular}

RFA, radiofrequency ablation; PR, partial response; DCR, disease control rate; TTP, time to progression; HCV, hepatitis C virus.

\section{Cancer attack by CTL activated by immune checkpoint inhibitor; anti-PD-1, anti-PD-L1, and anti-CTLA-4 antibodies}

Increased T-cell activation

Effective cancer attack by T-cell activation

Priming phase

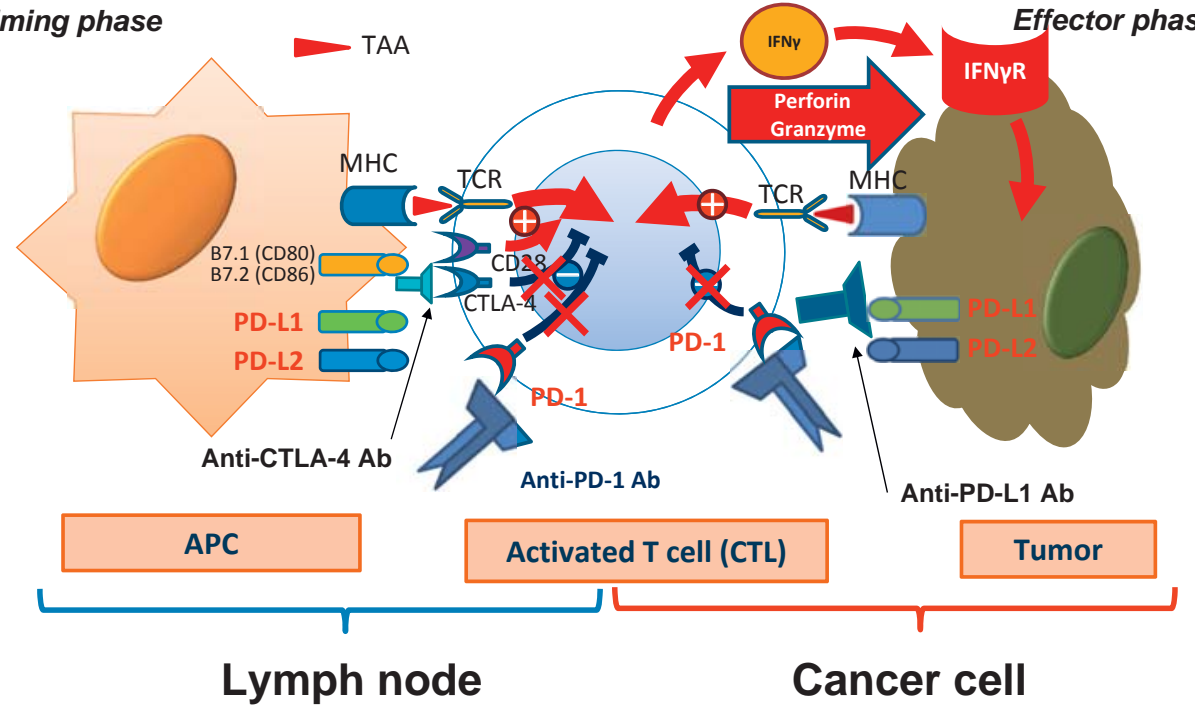

Fig. 4. Anti-PD-1, anti-PD-L1, and anti-CTLA-4 antibodies restore T-cell activation, leading to an effective cancer attack by the immune system. APC, antigen-presenting cell; TAA, tumor-associated antigen; TCR, T-cell receptor; CTL, cytotoxic T lymphocyte.

\section{Conclusion}

Here, we reviewed the current development status of molecular targeted agents and future trends in drug development for HCC. Because of the difficulties involved in developing novel agents, the positive outcome obtained with regorafenib is exiting news and may change 
the treatment paradigm for HCC. While expectations are rising for immunotherapy, new patient selection criteria are also emerging based on biological homogeneity as determined by biomarkers. This differs from the conventional selection criteria based on liver function and TNM stage. Furthermore, to reduce medical costs, it is necessary to put drug development into a broader perspective by, for example, incorporating new concepts such as the master protocol system into clinical trials.

\section{References}

1 Llovet JM, Ricci S, Mazzaferro V, Hilgard P, Gane E, Blanc JF, de Oliveira AC, Santoro A, Raoul JL, Forner A, Schwartz M, Porta C, Zeuzem S, Bolondi L, Greten TF, Galle PR, Seitz JF, Borbath I, Häussinger D, Giannaris T, Shan M, Moscovici M, Voliotis D, Bruix J; SHARP Investigators Study Group: Sorafenib in advanced hepatocellular carcinoma. N Engl J Med 2008;359:378-390.

2 Cheng AL, Kang YK, Chen Z, Tsao CJ, Qin S, Kim JS, Luo R, Feng J, Ye S, Yang TS, Xu J, Sun Y, Liang H, Liu J, Wang J, Tak WY, Pan H, Burock K, Zou J, Voliotis D, Guan Z: Efficacy and safety of sorafenib in patients in the AsiaPacific region with advanced hepatocellular carcinoma: a phase III randomised, double-blind, placebocontrolled trial. Lancet Oncol 2009;10:25-34.

3 Bruix J, Takayama T, Mazzaferro V, Chau GY, Yang J, Kudo M, Cai J, Poon RT, Han KH, Tak WY, Lee HC, Song T, Roayaie S, Bolondi L, Lee KS, Makuuchi M, Souza F, Berre MA, Meinhardt G, Llovet JM; STORM Investigators: Adjuvant sorafenib for hepatocellular carcinoma after resection or ablation (STORM): a phase 3, randomised, double-blind, placebo-controlled trial. Lancet Oncol 2015;16:1344-1354.

4 Okita K, Izumi N, Matsui O, Tanaka K, Kaneko S, Moriwaki H, Ikeda K, Osaki Y, Numata K, Nakachi K, Kokudo N, Imanaka K, Nishiguchi S, Okusaka T, Nishigaki Y, Shiomi S, Kudo M, Ido K, Karino Y, Hayashi N, Ohashi Y, Makuuchi M, Kumada H; Peretinoin Study Group: Peretinoin after curative therapy of hepatitis C-related hepatocellular carcinoma: a randomized double-blind placebo-controlled study.J Gastroenterol 2015;50:191-202.

5 Kudo M, Imanaka K, Chida N, Nakachi K, Tak WY, Takayama T, Yoon JH, Hori T, Kumada H, Hayashi N, Kaneko S, Tsubouchi H, Suh DJ, Furuse J, Okusaka T, Tanaka K, Matsui O, Wada M, Yamaguchi I, Ohya T, Meinhardt G, Okita K: Phase III study of sorafenib after transarterial chemoembolisation in Japanese and Korean patients with unresectable hepatocellular carcinoma. Eur J Cancer 2011;47:2117-2127.

6 Lencioni R, Llovet JM, Han G: Sorafenib or placebo in combination with transarterial chemoembolization (TACE) with doxorubicin-eluting beads (debdox) for intermediate-stage hepatocellular carcinoma (HCC): phase II, randomized, double-blind space trial (abstract). J Clin Oncol 2012;30(suppl 4):LBA154.

7 Meyer T, Fox R, Ma YT, Ross PJ, James M, Strugess R, Stubbs C, Wall L, Watkinson A, Hacking N, Evans T, Collins P, Hubner R, Cunningham D, Primrose JN, Johnson PJ, Palmer DH: TACE 2: a randomized placebo-controlled, double-blinded, phase III trial evaluating sorafenib in combination with transarterial chemoembolisation (TACE) in patients with unresectable hepatocellular carcinoma (HCC) - background (abstract). J Clin Oncol 2016;34(suppl 2016 ASCO Annu Meet):4018.

8 Kudo M, Han G, Finn RS, Poon RT, Blanc JF, Yan L, Yang J, Lu L, Tak WY, Yu X, Lee JH, Lin SM, Wu C, Tanwandee T, Shao G, Walters IB, Dela Cruz C, Poulart V, Wang JH: Brivanib as adjuvant therapy to transarterial chemoembolization in patients with hepatocellular carcinoma: a randomized phase III trial. Hepatology 2014;60: 1697-1707.

9 Park JW, Cheng AL, Kudo M, Park JH, Liang PC, Hidaka H, Izumi N, Heo J, Lee YJ, Sheen IS, Chiu CF, Arioka H, Morita S, Arai Y: A randomized, double-blind, placebo-controlled phase III trial of TSU-68 (Orantinib) combined with transcatheter arterial chemoembolization in patients with unresectable hepatocellular carcinoma. J Hepatol 2015;62:S189-S190.

10 Cheng AL, Kang YK, Lin DY, Park JW, Kudo M, Qin S, Chung HC, Song X, Xu J, Poggi G, Omata M, Pitman Lowenthal S, Lanzalone S, Yang L, Lechuga MJ, Raymond E: Sunitinib versus sorafenib in advanced hepatocellular cancer: results of a randomized phase III trial. J Clin Oncol 2013;31:4067-4075.

11 Johnson PJ, Qin S, Park JW, Poon RT, Raoul JL, Philip PA, Hsu CH, Hu TH, Heo J, Xu J, Lu L, Chao Y, Boucher E, Han KH, Paik SW, Robles-Aviña J, Kudo M, Yan L, Sobhonslidsuk A, Komov D, Decaens T, Tak WY, Jeng LB, Liu D, Ezzeddine R, Walters I, Cheng AL: Brivanib versus sorafenib as first-line therapy in patients with unresectable, advanced hepatocellular carcinoma: results from the randomized phase III BRISK-FL study. J Clin Oncol 2013;31:3517-3524.

12 Cainap C, Qin S, Huang WT, Chung IJ, Pan H, Cheng Y, Kudo M, Kang YK, Chen PJ, Toh HC, Gorbunova V, Eskens FA, Qian J, McKee MD, Ricker JL, Carlson DM, El-Nowiem S: Linifanib versus sorafenib in patients with advanced hepatocellular carcinoma: results of a randomized phase III trial. J Clin Oncol 2015;33:172-179.

13 Llovet JM, Decaens T, Raoul JL, Boucher E, Kudo M, Chang C, Kang YK, Assenat E, Lim HY, Boige V, Mathurin P, Fartoux L, Lin DY, Bruix J, Poon RT, Sherman M, Blanc JF, Finn RS, Tak WY, Chao Y, Ezzeddine R, Liu D, Walters I, Park JW: Brivanib in patients with advanced hepatocellular carcinoma who were intolerant to sorafenib or for whom sorafenib failed: results from the randomized phase III BRISK-PS study. J Clin Oncol 2013;31:35093516. 
14 Zhu AX, Kudo M, Assenat E, Cattan S, Kang YK, Lim HY, Poon RT, Blanc JF, Vogel A, Chen CL, Dorval E, PeckRadosavljevic M, Santoro A, Daniele B, Furuse J, Jappe A, Perraud K, Anak O, Sellami DB, Chen LT: Effect of everolimus on survival in advanced hepatocellular carcinoma after failure of sorafenib: the EVOLVE-1 randomized clinical trial. JAMA 2014;312:57-67.

15 Zhu AX, Park JO, Ryoo BY, Yen CJ, Poon R, Pastorelli D, Blanc JF, Chung HC, Baron AD, Pfiffer TE, Okusaka T, Kubackova K, Trojan J, Sastre J, Chau I, Chang SC, Abada PB, Yang L, Schwartz JD, Kudo M; REACH Trial Investigators: Ramucirumab versus placebo as second-line treatment in patients with advanced hepatocellular carcinoma following first-line therapy with sorafenib (REACH): a randomised, double-blind, multicentre, phase 3 trial. Lancet Oncol 2015;16:859-870.

16 Villanueva A: Rethinking future development of molecular therapies in hepatocellular carcinoma: a bottomup approach. J Hepatol 2013;59:392-395.

17 Santoro A, Rimassa L, Borbath I, Daniele B, Salvagni S, Van Laethem JL, Van Vlierberghe H, Trojan J, Kolligs FT, Weiss A, Miles S, Gasbarrini A, Lencioni M, Cicalese L, Sherman M, Gridelli C, Buggisch P, Gerken G, Schmid RM, Boni C, Personeni N, Hassoun Z, Abbadessa G, Schwartz B, Von Roemeling R, Lamar ME, Chen Y, Porta C: Tivantinib for second-line treatment of advanced hepatocellular carcinoma: a randomised, placebo-controlled phase 2 study. Lancet Oncol 2013;14:55-63.

18 Faivre SJ, Santoro A, Gane E, Kelley RK, Hourmand IO, Assenat E, Gueorguieva I, Cleverly A, Desaiah D, Lahn M, Raymond E, Benhadji KA, Giannelli G: A phase 2 study of galunisertib, a novel transforming growth factor-beta (TGF- $\beta$ ) receptor I kinase inhibitor, in patients with advanced hepatocellular carcinoma (HCC) and low serum alpha fetoprotein (AFP) (abstract). J Clin Oncol 2016;34(suppl 2016 ASCO Annu Meet):4070.

19 Kudo M: Regorafenib as second-line systemic therapy may change the treatment strategy and management paradigm for hepatocellular carcinoma. Liver Cancer 2016;5:235-244.

20 Terashima T, Yamashita T, Takata N, Nakagawa H, Toyama T, Arai K, Kitamura K, Yamashita T, Sakai Y, Mizukoshi E, Honda M, Kaneko S: Post-progression survival and progression-free survival in patients with advanced hepatocellular carcinoma treated by sorafenib. Hepatol Res 2016;46:650-656.

21 Reig M, Rimola J, Torres F, Darnell A, Rodriguez-Lope C, Forner A, Llarch N, Ríos J, Ayuso C, Bruix J: Postprogression survival of patients with advanced hepatocellular carcinoma: rationale for second-line trial design. Hepatology 2013;58:2023-2031.

22 Kudo M, Park JW, Obi S, Qin S, Assenat E, Umeyama Y, Chakrabarti D, Valota O, Fujii Y, Martini JF, Williams JA, Kang YK: Regional differences in efficacy/safety/biomarkers in a randomised study of axitinib in 2nd line patients (pts) with advanced hepatocellular carcinoma (HCC) (abstract). J Clin Oncol 2016;34(suppl 4S 2016 Gastrointest Cancers Symp):329.

23 Anthony B, El-Khoueiry IM, Todd S, Crocenzi, et al: Phase I/II safety and antitumor activity of nivolumab in patients with advanced hepatocellular carcinoma (HCC): CA209-040 (abstract). J Clin Oncol 2015; 33(suppl):LBA101.

24 Sangro B, Melero I, Yau TC, Hsu C, Kudo M, Crocenzi TS, Kim TY, Choo SP, Trojan J, Meyer T, Kang YK, Anderson J, Dela Cruz C, Lang L, Neely J, El-Khoueiry AB: Safety and antitumor activity of nivolumab (nivo) in patients (pts) with advanced hepatocellular carcinoma (HCC): interim analysis of dose-expansion cohorts from the phase 1/2 CheckMate-040 study (abstract). J Clin Oncol 2016;34(suppl 2016 ASCO Annu Meet):4078.

25 El-Khoueiry AB, Sangro B, Yau TC, Crocenzi TS, Welling TH, Yeo W, Chopra A, Anderson J, Dela Cruz C, Lang L, Neely J, Melero I: Phase I/II safety and antitumor activity of nivolumab (nivo) in patients (pts) with advanced hepatocellular carcinoma (HCC): interim analysis of the checkmate-040 dose escalation study (abstract). J Clin Oncol 2016;34(suppl 2016 ASCO Annu Meet):4012.

26 Sangro B, Park JW, Dela Cruz C, Anderson J, Lang L, Neely J, Shaw JW, Cheng AL: A randomized, multicenter, phase 3 study of nivolumab versus sorafenib as first-line treatment in patients (pts) with advanced hepatocellular carcinoma (HCC):CheckMate-459 (abstract). J Clin Oncol 2016;34(suppl 2016ASCO Annu Meet):TPS4147.

27 Abou-Alfa G, Sangro B, Morse M, Zhu AX, Kim RD, Cheng AL, Kudo M, Kang YK, Chan SL, Antal J, Boice J, Xiao F, Morris SR, Bendell J; 022 Study Group: Phase 1/2 study of durvalumab and tremelimumab as monotherapy and in combination in patients with unresectable hepatocellular carcinoma (HCC) (abstract). J Clin Oncol 2016;34(suppl 2016 ASCO Annu Meet):TPS3103.

28 Lung-MAP. http://wwwlung-maporg/. 